\title{
OSSIFICATION OF TRANSVERSE SCAPULAR LIGAMENT
}

Kalpana Thounaojam, Renuca Karam, N. Saratchandra Singh

1. Assistant Professor. Department of Anatomy, JNIMS, Porompat, Imphal.

2. Demonstrator. Department of Anatomy, JNIMS, Porompat, Imphal.

3. Professor. Department of Anatomy, RIMS, Lamphelpat, Imphal.

\section{CORRESPONDING AUTHOR:}

Dr. Kalpana Thounaojam,

Assistant Professor,

Anatomy Department,

JNIMS, Porompat, Imphal- 795005

E-mail: kalpanathounaojam@yahoo.co.in

KEY WORDS: Scapula, Suprascapular notch, Transverse scapular ligament, Suprascapular nerve

INTRODUCTION: The scapula is a triangular, flattened bone. It extends from the second to the seventh rib in the posterolateral aspect of thorax. Its superior border extends between superior and lateral angles. The suprascapular notch is located in this border near the root of coracoid process. This notch is converted into a foramen called suprascapular foramen by transverse scapular ligament (suprascapular ligament). This ligament is a flat fasciculus which narrows its attachments to the base of the coracoid process and medial side of the suprascapular( scapular) notch . This ligament is sometimes ossified ${ }^{1}$. The suprascapular nerve passes through the foramen and the suprascapular vessels cross above the ligament. The anatomical knowledge of this foramen is of extreme importance for clinicians as it can be a risk factor during surgical explorations involving a suprascapular nerve decompression. ${ }^{2}$

MATERIALS AND METHODS: 100 (50- left and 50- right) dry scapulae were studied to search for ossification of transverse scapular ligament.

RESULT: Ossified transverse scapular ligament (as shown in fig.) was observed in two dry left scapulae showing the presence of suprascapular foramen in dry scapula. Ossified transverse scapular ligament was not seen in right side. The ossification was complete in the two ossified ligaments. According to this study, the incidence of ossification of transverse scapular ligament is $2 \%$. Ossification of left transverse scapular ligament is seen in $4 \%$ of individuals.

DISCUSSION: The documented variations of the superior transverse scapular ligament include calcification, partial or complete ossification and multiple bands. ${ }^{3}$

The ossification of the STSL has been reported to be $18 \%$ for the partial and $5 \%$ for the complete type. ${ }^{3}$ Past studies have reported a 3.7\% - 4\% incidence of partial ossification of STSL. ${ }^{5,6}$ In the present study, the incidence of complete ossification of STSL is $2 \% .{ }^{3}$ In another study, suprascapular foramen was present in 25 right and in 12 left sided scapulae i.e., $10.57 \%$ incidence ${ }^{2}$.Another study reported a case of completely ossified left superior transverse scapular ligament.7The presence of an ossified STSL may also pose a challenge during decompression of the suprascapular notch if the condition is not fully appreciated. There is a report of a familial case of calcification of superior transverse scapular ligament, affecting a 58 year old man and his son who had calcification of superior transverse scapular ligament, causing entrapment neuropathy of the suprascapular nerve ${ }^{8}$. 
In the diagnosis of suprascapular nerve entrapment syndrome, these variations in the anatomy of the superior transverse scapula ligament sometimes feature in the hierarchy of possible etiologic factors. ${ }^{4}$ They usually present with vague pain radiating across scapula, dull shoulder ache, limitation of shoulder joint movements and wasting of supraspinatus and infraspinatus. 9,10

CONCLUSION: Ossification of transverse scapular ligament is not extremely rare as was thought to be. In our study, the incidence of ossification of transverse scapular ligament is $2 \%$. Ossification of transverse scapular ligament may cause entrapment neuropathy of suprascapular nerve.

\section{REFERENCES:}

1. Standring S, Johnson D, Collins P, Healy JC; Gray's Anatomy. The Anatomical Basis of Clinical Practice in Pectoral girdle and upper limb. 40 th Edn. Elsevier Churchill Livingstone, Philadelphia 2008, pp 775-906.

2. S D Jadhav, R J Patil, P P Roy, M P Ambali, M A Doshi, Rajeev R Desai. Supra- scapular foramen in Indian dry scapulae.National Journal of Clinical Anatomy.2012; 1(3) 133-135.

3. Ticker JB, Djurasovic M, Strauch RJ, April EW, Pollock RG, Flatow EL, Bigliani LU. The incidence of ganglion cysts and other variations in anatomy along the course of the suprascapular nerve. J Shoulder Elbow Surg. 1998; 7 472-478.

4. Callahan, J. D, Scully T.B, Shapiro S. A, Worth R.M. Suprascapular nerve entrapment. A series of 27 cases. J. Neurosurg. 1991; 74 893-6.

5. Hrdlicka A. The scapula: Visual observations. Am J Phys Anthropol. 1942; 2 73-94.

6. Rengachary SS, Neff JP, Singer PA, Brackett CF. Suprascapular nerve entrapment neuropathy: A clinical, anatomical and comparative study. Part 1: Clinical study. Neurosurgery. 1979; 5 441-445.

7. Mohd. Azim Khan. Complete Ossification of the Superior Transverse Scapular Ligament in an Indian Male Adult. Int. J. Morphol. 2006; 24(2) 195-196.

8. Cohen, S. B.; Dnes,D.M. Moorman, C.T. Familial calcification of the superior transverse scapula ligament causing neuropathy. Clin. Orthop. Rel. Res. 1997; 334 131-5.

9. Clein LJ. Suprascapular entrapment neuropathy. J Neurosurg. 1975; 43 337-42.

10. Post M, Mayer J. Suprascapular nerve entrapment: diagnosis and treatment. Clin Orthop 1987; 223 126-36.

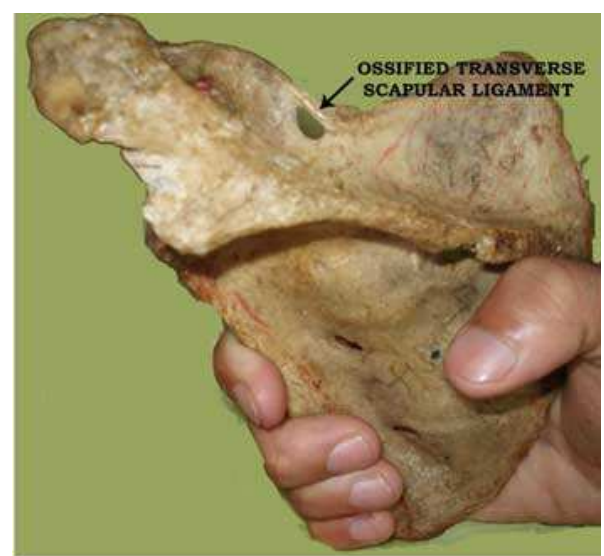

Fig: Ossification of transverse scapular ligament in a left dry scapula 